\title{
KEPUASAN KERJA DAN LOYALITAS KERJA PADA GURU HONORER SMA SWASTA BUKITTINGGI
}

\author{
Silvia Fitria dan Suci Rahma Nio \\ Jurusan Psikologi, Universitas Negeri Padang, Sumatera Barat \\ Email : Silviafitria15@gmail.com, sucirahmanio@gmail.com
}

\begin{abstract}
Abstrak
Penelitian ini bertujuan untuk mengetahui bagaimana hubungan kepuasan kerja dengan loyalitas kerja pada guru honorer SMA Swasta Bukittinggi. Desain penelitian yang digunakan kuantitatif korelasional dengan populasi Guru honorer SMA Swasta Bukittinggi. Sampel penelitian berjumlah 60 orang yang dipilih menggunakan teknik total sampling. Pengumpulan data dilakukan dengan menggunakan skala kepuasan kerja yang berjumlah 36 butir pertanyaan dan skala loyalitas kerja yang berjumlah 31 butir yang disusun berdasarkan skala likert. Teknik analisis data yang digunaka adalah uji korelasi. Hasil dari uji korelasi $p=0,674(p<0,01)$ yang berarti terdapat hubungan positif yang sangat signifikan antara kepuasan kerja dengan loyalitas kerja pada guru honorer SMA Swasta Bukittinggi.

Kata kunci : Kepuasan kerja, loyalitas kerja, guru honorer.
\end{abstract}

\section{JOB SATISFACTION AND WORK LOYALTY AMONG CONTRACT TEACHERS IN PRIVATE VOCATIONAL SCHOOL BUKITTINGGI}

\begin{abstract}
This study aimed to determine the correlation between job satisfaction and job loyalty of honorary teachers at Bukittinggi Private High School. The research design used correlational quantitative with a population of honorary teachers at SMA Swasta Bukittinggi. The research sample consisted of 60 people who were selected using total sampling technique. The data was collected using a work satisfaction scale, which amounted to 36 questions and a work loyalty scale, which amounted to 31 items, which were arranged based on a Likert scale. The data analysis technique used is the correlation test. The results of the correlation test $p=0.674$ ( $p$ $<0.01)$, which means that there is a very significant positive relationship between job satisfaction and job loyalty of honorary teachers of Bukittinggi Private High School.
\end{abstract}

Keywords : Job satisfaction, job loyalty, honorary teacher 


\section{Pendahuluan}

Pendidikan aktivitas belajar mengajar yang dilakukan individu yang kompeten terhadap siswa secara aktif mengembangkan potensi yang dimiliki dalam diri setiap siswa untuk memiliki penegtahuan agama yang lebih baik, pengontrolan diri, kepribadian, kecerdasan serta bakat yang nanti akan berguna untuk diri sendiri, orang-orang disekitar dan negara yang dijalankan oleh seseorang yang disebut guru. Di Indonesia terdapat jutaan jiwa manusia dengan jenis-jenis pekerjaan, bahkan memiliki suatu profesi sesuai keinginannya masing-masing, contohnya saja menjadi guru yang banyak disukai oleh banyak masyarakat karena dapat menyalurkan ilmu kepada orang banyak dalam pendidikan (Meiza, 2016).

Pekerjaan guru di Indonesia dibagi menjadi dua yaitu guru permanen dan guru non permanen. Guru permanen adalah mereka yang telah menjadi pegawai negeri dan di tugaskan ke sekolah sekolah tertentu. Guru non permanen atau honorer adalah ia yang dibayar berdasarkan jam mengajar setiap bulan, yang sering disebut guru honorer (Sariwulan, Agung, Sudrajat, \& Atmadiredja, 2019).

Pekerja honorer adalah seseorang guru yang diangkat oleh petinggi kepegawaian dalam pemerintahan untuk melaksanakan tugas tertentu yang upah atau gaji menjadi beban anggaran pendapatan dan belanja Negara (peraturan.bpk.go.id, 2005). Isu guru honorer yaitu kehidupan guru honorer yang jauh dari kata sejahtera, dimana sejumlah keluhan terkuak bahwa gaji yang jauh lebih kecil dari Upah Minimum Provinsi ataupun Upah Minimum Kabupaten Atau Kota, serta tidak adanya tunjangan yang didapat seperti guru yang berstatus ASN. Jadi secara finansial, para guru honorer tidak secure dan mereka juga tidak mendapatkan hak yang sama dengan guru yang berstatus ASN Seperti tunjangan sertifikasi (Tri, 2019).

Pada tingkat nasional jumlah Guru Honorer SMA berjumlah sebanyak 152,040 orang. Sedangkan pada tingkat Provinsi sendiri terkhusus Provinsi Sumatera Barat berjumlah sebanyak 4.442 orang yang berstatus sebagai guru honorer di SMA-SMA yang ada di provinsi Sumatera Barat (statistik.data.kemdikbud.go.id, n.d.). Upah Minimum Regional (UMR) Kabupaten Bekasi sendiri termasuk yang terbesar di Indonesia yaitu mencapai 4,1 Jutaan, tapi ternyata besarnya angka tersebut tidak berlaku kepada guru honorer yang berada di kota tersebut. Pada tahun lalu, 5000 guru yang pernah bergabung dalam Forum Pegawai Honorer Indonesia (FPHI) pernah mengajukan unjuk rasa atau demo di depan kantor Bupati Bekasi, mereka menuntut kenaikan gaji yang sepadan sesuai beban kerja mereka. Pendapatan guru honorer disana hanya berkisar Rp. $150.000-300.000 /$ bulan. Besar nya gaji tersebut tentu tidak bisa menutupi semua kebutuhan pokok yang terus mengalami peningkatan setiap tahunnya (Budi, 2019). Keadaan ini membaut loyalitas guru honorer di uji untuk terus mengajar murid-muridnya.

Loyalitas adalah ikatan terbentuk dari rasa ketertarikan, perasaan ingin menjadi bagian dari instansi tersebut. Serta siap untuk berkontribusi dengan menggabungkan rasa percaya, selaras dan sedia untuk setia akan setiap areahan dalam bekerja (Adler \& Adler, 1988). Menurut Hasibuan (dalam Sianipar \& Salim, 2019) loyalitas adalah bagian dalam diri karyawan untuk melakukan penilaian mencakup kesetiaan pada pekerjaan, posisi di instansi,kesetiaan ini terlihat ketika karyawan ikut membela dan menjaga instansi tersebut. Semakin banyak seseorang karyawan merasa puas dengan pekerjaan dan lingkungan, maka semakin besar kemungkinan rasa komitmen atau loyal karyawan tersebut terhadap organisasinya (Rajput, Singhal, \& Tiwari, 2016).

Loyalitas adalah tingkat kesesuaian karyawan terhadap instansinya. Hubungan yang sesuai yaitu hubungan yang kuat, positif, dinamis serta berbasis internal akan keyakinan sasaran suatu organisasi. Bukan hanya menilai manfaat ia dalam organisasi tetapi juga adanya ikatan emosional kesetiaannya terhadap organisasi / tempat ia bekerja, dan keinginan untuk terus berada dalam organisasi tersebut 
(Arqawi, Al, Naser, \& Shobaki, 2018). Namun, Berdasarkan hasil wawancara pada 10 Maret 2020 dengan guru $\mathrm{R}$, terdapat beberapa guru yang masih merasakan adanya perbedaan srata diantara guru yang ditampilkan oleh pemangku kepentingan di sekolah tersebut.

Wawancara yang dilakukan pada Selasa, 10 Maret 2020 kepada guru honorer SMA Swasta di Kota Bukittinggi perihal pekerjaan menjadi seorang guru honorer disekolah swasta. Menurut pandangan sebagian guru, menjadi seorang guru adalah pekerjaan yang menyenangkan, terlebih lagi ketika murid yang diajar mengerti dengan apa yang ajarkan, memiliki antusias dengan materi yang disampaikan, dan kepuasan tersendiri yang di rasakan ketika menjadi guru ialah ketika la mampu memberikan dorongan, kebahagiaan, kekuatan serta nilai-nilai moralitas kepada siswa penerus bangsa, terlebih lagi memiliki rekan kerja yang satu visi dengannya demi mencerdaskan putra - putri bangsa, meski dengan gaji yang kecil tetapi guru tersebut tetap dengan senang hati melakukan pekerjaan mulia ini.

Berdasarkan hasil dari studi wawancara yang dilakukan, selain rasa kebahagiaan dan kepuasaan menjadi seorang guru, juga adanya keluhan ketika menjadi seorang guru, diantaranya ada pekerjaan tugas tambahan yang diberikan oleh pihak sekolah kepada beberapa guru, ada beberapa guru merasa bahwa tugas tambahan ini hanya diberikan kepada guru tertentu saja, bahkan ada guru yang tidak pernah mendapat tugas tambahan, sehingga tugas tambahan ini bisa menjadi beban bagi seorang guru. Beban inilah yang bisa berdampak kepada loyalitas seorang guru, karena adanya tugas tambahan ini membuat guru sibuk dengan tugas tambahannya dan seringkali tugas pokoknya terabaikan. Hal ini bukan menjadi persoalan iri bagi seorang guru, tetapi ini merupakan suatu bentuk ketidakadilan yang dirasakan, sebab tugas tambahan yang diberikan tidak secara adil, sehingga disinilah nampaknya adanya perbedaan strata diantara guru yang ditampilkan oleh pemangku kepentingan menyebabkan tidak adanya sistem pemerataan, baik terhadap giliran maupun kompensasi yang setimpal atas tugas tambahan yang guru tersebut kerjakan.

Selain itu, kurangnya rasa tanggung jawab dari pribadi guru tersebut, contohnya pada saat diskusi atau rapat berlangsung, banyak diantaranya sibuk dengan gadget masing-masing, terlihat kurangnya kontribusi guru akan ide - ide dan. Dan bahkan ada beberapa dari beliau yang memutuskan untuk tidak hadir dalam rapat bulanan, karena merasa kurang memiliki tanggung jawab dalam keikutsertaan pada saat rapat berlangsung sehingga munculah pemikiran tanpa kehadiran mereka pun rapat akan tetap berjalan. Hal inilah yang akan menjadi alasan beberapa oknum guru tersebut tidak loyal terhadap pekerjaannya. Dan membuat kepuasaan kerja pada guru honorer terganggu.

Menurut Teori kepuasan kerja yang dikemukakan oleh (Locke, 1969) bahwa kepuasan kerja merupakan perasaan bahagia yang berkiatan dengan emosional yang dihasilkan dari nilai-nilai yang ada pada pekerjaannya, Dan juga sesuai dengan teori (Basalamah, 2012) seseorang merasa puas ketika ia memiliki hubungan yang baik dengan rekan kerja serta kemampuan ia dalam menyampaikan materi sehingga para murid merasa antusias dengan apa yang ia sampaikan selama proses belajar. Kepuasan kerja juga dipengaruhi oleh berbagai faktor yaitu gaji, kemajuan, peluang, manajemen, kelompok kerja serta kondisi kerja (Rajput et al., 2016).

Berdasarkan penelitian terdahulu (Hadiutama, 2008) memiliki hubungan yang positif signifikan dilihat dari hasil korelasi rank spearman 0,244 dengan hasil signifikan 0,015, hal ini berarti jika karyawan senata dharma semakin puas maka akan loyal. Dari penjelasan penelitian terdahulu tersebut dapat simpulkan bahwa kepuasan kerja memiliki hubungan yang positif terhadap variabel loyalitas kerja. Berdasarkan pemaparan fenomena yang peneliti jelaskan diatas, peneliti ingin mengetahui fenomena lebih dalam lagi dengan penelitian yang berjudul "hubungan kepuasan kerja dengan loyalitas kerja pada guru honorer sma swasta Bukittinggi" 


\section{Metode Penelitian}

Metode penelitian yang digunakan adalah metode penelitian kuantitatif. Merode penelitian kuantitatif merupakan metode penelitian yang berdasarkan pada filsafat positivisme, yang berguna untuk meneliti populasi atau sampel tertentu, pengumpulan data dalam penelitian ini menggunakan instrumen penelitian yaitu kuisioner. analisis data bersifat kuantitatif dengan tujuan untuk menguji hipotesis yang telah ditetapkan (Sugiyono, 2013).

Metode kuantitatif korelasional adalah metode penelitian yang digunakan untuk melihat hubungan antara satu variabel bebas dengan variabel terikat (Yusuf, 2010).Teknik sampling yang digunakan adalah total sampling. Total sampling adalah jumlah populasi dan jumlah sampel sama. Data yang terkumpul kemudian dilakukan uji normalitas, linearitas, kemudian dianalisis menggunakan uji korelasi product moment

\section{Subjek penelitian}

Subjek pada penelitian ini adalah seluruh guru honorer SMA Swasta Bukitinggi yang terdiri dari 3 SMA Swasta di Bukittinggi yang berjumlah sebanyak 60 orang repsonden.

\section{Variabel dan instrumen penilitian}

Terdapat dua variabel dalam penelitian ini, yaitu kepuasan kerja sebagai variabel X ATAU variabel bebas dan loyalitas kerja sebagai varaibel $\mathrm{Y}$ atau varaibel terikat.

Defenisi operasional untuk kepuasan kerja ialah total skor jawaban responden terhadap skala kepuasan kerja berdasarkan aspek-aspek kepuasan kerja yang terdiri atas, gaji, promosi, supervisi, tunjangan, imbalan kontingen, prosedur, rekn kerja, sifat pekerjaan, dan komunikasi yang disusun oleh (Spector, P, 1985).

Defenisi operasional loyalitas kerja ialah total skor jawaban responden terhadap skala loyalitas kerja yang disusun oleh peneliti sendiri berdasarkan aspek-aspek loyalitas kerja yang teredeiri atas, taat pada aturan, tanggung jawab pada instansi, kemauan untuk bekerja, rasa memiliki, hubungan antar pribadi, kesukaan terhadap pekerjaan.

Pengumpulan data dilakukan menggunakan kuisioner. Dengan menggunakan skala, yaitu skala kepuasan kerja dengan 4 alternatif jawaban yaitu Sangat Setuju (SS), Setuju (S), tidak setuju (TS), dan Sangat Tidak Setuju (STS). Sebelum dilakukan penelitian, terlebih dahulu peneliti melakukan uji coba terhadap 36 aitem loyalitas kerja untuk mengetahui reliabilitas dan validitasnya dan uji coba dilakukan kepada 30 orang guru honorer. Suatu item dikatakan valid apabila nilai $r$ tabel $>r$ Hitung dengan df 30-2=28 dengan nilai $r$ tabel $=0,360$. Setelah dilakukan pengolahan data pada hasil uji coba, ditemukan hasil sebagai berikut.

\begin{tabular}{cccc}
\hline Alat ukur & Jumlah item & Validitas & reliabilitas \\
\hline Loyalitas kerja & 36 & $0,328-0,788$ & 0,742 \\
\hline
\end{tabular}

\section{Prosedur dan analisis data}

Terdapat dua tahapan pada penelitian ini. Tahap pertama adalah Tahap persiapan, tahap awal dalam penelitian yang dilakukan oleh peneliti sendiri. Alat ukur akan dipersiapakan dan akan peniliain serta feedback dari ahli atau profesional judgement. Skala loyalitas kerja ini terdiri dari 6 aspek dan terdapat 31 butir aitem.

Tahap yang kedua adalah Uji coba skala dilakukan pada tanggal 6 - 9 Juni 2020 pada guru honorer SMAS X dengan jumlah responden sebanyak 30 orang. Pengisian skala dilakukan sendiri oleh responden melalui google from. Selanjutnya, pengambilan data penelitian dilakukan pada tanggal 16 - 30 Juni 2020 pada guru honorer SMAS Bukittinggi dengan jumlah responden sebanyak 60 orang. 
Penelitian yang awalnya dilakukan pada 6 SMAS Bukittinggi, hanya bisa terlaksana pada 3 SMAS Bukittinggi saja. Hal ini dikarenakan para guru sudah membagikan rapor dan itupun secara daring (online). Serta tidak datang ke sekolah hingga adanya pemberitahuan dari dinas pendidikan. Analisis data yang digunakan dalam penelitian ini adalah tenik analisis korelasi, korelasi ialah teknik yang digunakan untuk mencari hubungan antara dua variabel yang akan di teliti oleh peneliti yaitu variabel bebas dan variabel terikat (Winarsunu, 2009).Uji korlasi yang digunakan yaitu product moment Pearson. Tujuannnya untuk mengetahui bagaimana hubungan variabel bebas dan variabel terikat (Sugiyono, 2013). Didalam mengolah data, peneliti dibantu dengan aplikasi SPSS versi 20 for windows.

\section{Hasil Penelitian}

Dalam penelitian ini yang menjadi subjek adalah guru-guru honorer SMA Swasta Bukittinggi. Dimana penelitian dilakukan pada 3 SMA Swasta Bukittinggi yang memiliki jumlah responden sebanyak 60 orang guru. Pada setiap sekolah hanya ada 20 orang guru honorer yang mengajar. Subjek dipilih sesuai dengan kriteria sebelumnya, yaitu guru honorer SMAS Bukittinggi sehingga didapatkan 60 orang subjek didalam penelitian ini. Kepada setiap subjek, diberikan skala penelitian yang telah disusun oleh peneliti, yaitu skala loyalitas kerja dan skala kepuasan kerja. Hasil penelitian, diperoleh skor hipotetik dan skor empiris dari skala kepuasan kerja dengan loyalitas kerja. Rata-rata hipotetik dari skala kepuasan kerja sebesar 90, sedangkan untuk rata-rata empirisnya sebesar 95,82.

Tabel Kriteria Kategori Skala kepuasan kerja dan loyalitas kerja

\begin{tabular}{ccccc}
\hline \multirow{2}{*}{ Kategori } & \multicolumn{2}{c}{ Job Satisfaction Survey } & \multicolumn{2}{c}{ Loyalitas kerja } \\
\cline { 2 - 5 } & Frekuensi & Persentase (\%) & Frekuensi & Persentase (\%) \\
\hline Sangat rendah & 0 & $0 \%$ & 0 & $0 \%$ \\
Rendah & 0 & $0 \%$ & 0 & $0 \%$ \\
Sedang & 10 & $16,7 \%$ & 1 & $1,67 \%$ \\
Tinggi & 30 & $50 \%$ & 23 & $38,33 \%$ \\
Sangat tinggi & 20 & $33,3 \%$ & 36 & $60 \%$ \\
Total & 60 & $100 \%$ & 60 & $100 \%$ \\
\hline
\end{tabular}

Hasil penggolongan kategorisasi skala kepuasan kerja didapatkan katergori subjek 20 orang $(33,3 \%)$ dalam aktegori sangat tinggi, 30 orang $(50 \%)$ dalam kategori tinggi, 10 orang $(16,7 \%)$ dalam kategori sedang, dan kategori rendah dan sangat rendah 0 orang (0\%). Jadi dapat dilihat bahwa kepuasan kerja subjek lebih tinggi, artinya kepuasan kerja guru honorer SMA Swasta Bukittinggi berada di kategori tinggi. Pada variabel loyalitas kerja, terlihat bahwa subjek berada di kategori sangat tinggi sebanyak 36 orang (60\%), pada kategori tinggi sebanyak 23 orang $(38,33 \%)$, kategori sedang sebanyak 1 orang $(1,67 \%)$, kategori rendah tidak ada $(0 \%)$, dan kategori sangat rendah tidak ada $(0 \%)$. Jadi dapat ditarik kesimpulan secara keseluruhan subjek dalam penelitian ini kebanyakan memiliki loyalitas kerja yang sangat tinggi.

Berdasarakan hasil pengkategorian per aspek kepuasan kerja, didapatkan menunjukkan bahwa pada aspek gaji pada kategori sangat tinggi - rendah tidak ada (0\%). Dan pada kategori sangat rendah sebanyak 60 orang sebesar (100\%). Pada aspek promosi didapatkan sebanyak 6 orang (10\%) dalam kategori sangat tinggi, 28 orang $(46,67 \%)$ dalam kategori tinggi, 11 orang $(18,33 \%)$ dalam kategori sedang, 15 orang (25\%) dalam kategori rendah dan kategori sangat rendah tidak ada (0\%). 
Pada aspek supervisi pada kategori sangat tinggi - rendah tidak ada (0\%). Dan pada kategori sangat rendah sebanyak 60 orang sebesar (100\%).

Pada aspek tunjangan didapatkan sebanyak 13 orang $(21,67 \%)$ dalam kategori sangat tinggi, 23 orang $(38,33 \%)$ dalam kategori tinggi, 3 orang (5\%) dalam kategori sedang, 21 orang (35\%) dalam kategori rendah, dan pada kategori sangat rendah tidak ada. Pada aspek imbalan kontingen terdapat 18 orang $(30 \%)$ dalam kategori sangat tinggi, 40 orang $(66,67 \%)$ dalam kategori tinggi, pada kategori sedang tidak ada, 2 orang $(3,33 \%)$ dalam kategori rendah dan pad kategori sangat rendah tidak ada. Pada aspek prosedur kategori sangat tinggi - rendah tidak ada (0\%). Dan pada kategori sangat rendah sebanyak 60 orang sebesar (100\%). Pada aspek rekan kerja 23 orang (38,33\%) dalam kategori sangat tinggi, 32 orang $(53,33 \%)$ dalam kategori tinggi, pada kategori sedang dan snagat rendah tidak ada (0\%). 5 orang $(8,33 \%)$ dalam kategori rendah. Pada aspek sifat pekerjaan terdapat 25 orang $(41,66 \%)$ dalam kategori sangat tinggi, 28 orang $(46,66 \%)$ dalam kategori tinggi, pada kategori sedang dan sangat rendah tidak ada $90 \%) .7$ orang $(11,66 \%)$ pada kategori rendah. Pada aspek terakhir, komunikasi terdapat 22 orang $(36,66 \%)$ dalam kategori sangat tinggi, 16 orang $(26,66 \%)$ dalam kategori tinggi, 3 orang (5\%) dalam kategori sedang, 18 orang (30\%) dalam kategori rendah dan 1 orang $(1,66 \%)$ dalam kategori sangat rendah.

Berdasarkan penjabaran diatas, bahwa pada aspek gaji terletak pada kategori sangat rendah yang terdapat 60 orang (100\%). Pada aspek promosi terletak pada kategori tinggi yang terdapat 28 orang (46,67\%). Pada aspek supervisi terletak pada kategori super rendah yang terdapat 57 orang (95\%). Pada aspek tunjangan terletak pada kategori tinggi yang terdapat 23 orang (38,33\%). Pada aspek imbalan kontingen terletak pada kategori tinggi yang terdapat 40 orang $(66,67 \%)$. Pada aspek prosedur terletak pada kategori sangat rendah yang terdapat 60 orang $(100 \%$. Pada aspek rekan kerja terletak pada kategori tinggi yang terdapat 32 orang (53,33\%). Pada aspek sifat pekerjaan terletak pada kategori tinggi yang terdapat 28 orang $(46,675)$. Pada aspek komunikasi terletak pada kategori sanggat tinggi yang terdapat sebanyak 22 orang $(36,66 \%)$. Oleh karena itu, untuk rata-rata keseluruhan pada semua aspek kepuasan kerja terletak pada kategori tinggi.

Kemudian, Pada aspek taat pada peraturan didapat mean empiris sebesar 10,23 dengan mean hipotetiknya sebesar 7,5. Pada aspek tanggjung jawab mean empiris sebesar 20,85 dengan mean hipotetiknya 15. Pada aspek kemauan untuk bekerja sama terdapat mean empiris sebesar 20,91 dengan mean hipotetiknya 15 . Pada aspek rasa memiliki terdapat mean empiris sebesar 20,55 dengan mean hipotetiknya 15. Pada aspek hubungan antar pribadi terdapat mean empiris sebesar 16,61 dengan mean hipotetiknya 12,5. Dan pada aspek kesukaan terhadap pekerjaan terdapat mean empiris sebesar 15,35 dengan mean hipotetiknya 12,5. Dengan begitu dapat ditarik kesimpulan secara umum subjek penelitian ini memiliki loyalitas kerja yang tinggi pada setiap masing-masing aspek dari pada populasi pada umumnya. Hal ini menunjukkan bahwa mean pada skor empiris di setiap masing-masing aspek loyalitas kerja lebih tinggi dari pada mean hipotetiknya.

Pengkategorian subjek pada per aspek loyalitas kerja, pada aspek taat pada peraturan didapat sebanyak 44 orang $(73,33 \%)$ dalam kategori sangat tinggi, 13 orang $(21,67 \%)$ dalam kategori tinggi, 3 orang (5\%) kategori sedang, dan kategori rendah \& sangat rendah tidak ada (0\%). Pada aspek tanggungjawab pada instansi terdapat sebanyak 43 orang $(71,67 \%)$ dalam kategori sangat tinggi, 15 orang $(25 \%)$ kategori tinggi, 2 orang $(3,33 \%)$ kategori sedang, dan kategori rendah \& sangat rendah tidak ada (0\%). Aspek kemauan untuk bekerjasama terdapat 44 orang $(73,33 \%)$ dalam kategori sangat tinggi, 13 orang $(21,67 \%)$ dalam kategori tinggi, 3 orang $(5 \%)$ kategori sedang, dan kategori rendah \& sangat rendah tidak ada (0\%). Aspek rasa memiliki terdapat 39 orang (65\%) dalam kategori sangat tinggi, 19 orang $(31,67 \%)$ dalam kategori tinggi, 2 orang $(3,33 \%)$ dalam kategori sedang, dan kategori 
rendah \& sangat rendah tidak ada (0\%). Selanjutnya, aspek hubungan antar pibadi terdapat 31 orang $(51,67 \%)$ dalam kategori sangat tinggi, 23 orang (38,33\%) dalam kategori tinggi, 6 orang (10\%) dalam kategori sedang, dan kategori rendah \& sangat rendah tidak ada (0\%). Aspek terakhir dalam loyalitas yaitu kesukaan terhadap pekerjaan terdapat sebanyak 12 orang (20\%) kategori sangat tinggi, 39 orang (65\%) dalam kategori tinggi, 9 orang (15\%) dalam kategori sedang, dan kategori rendah \& sangat rendah tidak ada (0\%). Oleh karena itu, dapat disimpulkan bahwa rata-rata secara keseluruhan aspek pada loyalitas tinggi terletak pada kategori sangat tinggi.

Pada uji normalitas ditemukan hasil berupa nilai $(P)$ untuk skala kepuasan kerja adalah 0,122 $(P>0,05)$ Dan nilai $(P)$ untuk skala loyalitas kerja adalah 0,245 . Berdasarkan temuan tersebut, maka kedua skala dinyatakan berdistribusi normal. Selanjutnya pada uji linearitas ditemukan diketajui jika nilai $P$ untuk linearity adalah $0,000(<0,05)$ dan nilai $F=73,740$. Hal tersebut menunjukkan jika hubungan kedua variabel linear. Sedtelah dilakukan uji normalitas dan linearitas, selanjutnya dilakukan hasil untuk uji korelasi yaitu 0,674. Nilai ini menunjukkan jika kedua variabel memiliki otoritas hubungan antara variabel kepuasan kerja dan loyalitas kerja berada pada kategori $p=0,000$ $(p<0,01)$, sehingga terdapat hubungan posistif yang sangat signifikan antara kepuasan kerja dengan loyalitas kerja. Artinya semakin tinggi kepuasan kerja maka semakin tinggi loyalitas kerja pada guru honorer SMA Swasta Bukittinggi. Begitupun sebaliknya semakin rendah kepuasan kerja maka semakin rendah pula loyalitas kerja pada guru honorer SMA Swasta Bukittinggi.

\section{Pembahasan}

Penelitian ini bertujuan untuk melihat hubungan antara kepuasan kerja dengan loyalitas kerja pada guru honorer SMA Swasta Bukittinggi. Berdasarkan hasil pengolahan data, terlihat bahwa antara kepuasan kerja dengan loyalitas kerja memiliki hubungan yang sangat signifikan, dengan arah korelasi positif. Sehingga hipotesis alternatif dalam penelitian ini dapat diterima, yaitu semakin tinggi kepuasan kerja yang di miliki guru honorer SMA Swasta Bukittinggi, maka semakin tinggi pula loyalitas kerja yang dimiliki oleh guru honorer SMA Swasta Bukittinggi.

Penjelasan adanya hubungan antara kepuasan kerja dengan loyalitas kerja ini diperkuat dengan hasil penelitian yang dilakukan oleh Mariani,R. \& Irvani,H (Mariana, R \& Irfani, 2015) berdasarkan penelitian yang mereka lakukan, diperoleh korelasi yang sangat signifikan antara variabel kepuasan kerja dengan loyalitas kerja, ini berarti adanya hubungan antara kepuasan kerja dengan loyalitas kerja perawat honour di RSUD Kab. Padang Pariaman. Apabila perawat honour di RSUD Kab. Padang Pariaman memiliki kepuasan kerja yang tinggi maka perawat tersebut akan mempunyai loyalitas kerja yang tinggi, begitu juga sebaliknya apabila perawat honour di RSUD tersebut memiliki kepuasan kerja yang rendah maka akan memiliki loyalitas kerja yang rendah pula. Selain itu hasil penelitian ini juga sependapat dengan ungkapan Wibowo (Mariana \& Irfani, 2015) bahwa karyawan yang memiliki tingkat kepuasan kerja yang tinggi menunjukkan sikap kerja positif terhadap pekerjaan serta akan bertanggung jawabnya atas kerjanya.

Berdasarkan tabel pengkategorian skala kepuasan kerja mendapatkan hasil kategori tinggi. Kepuasan kerja ialah sikap seseorang karyawan yang tercemin dari penilaian karyawan tersebut dalam merasakan pekerjaan secara keseluruhan (Spector, P, 1985). Begitu pula dengan teori kepuasan kerja yaitu Karyawan yang mempunyai kepuasan kerja akan memiliki rasa keterikatan dan komitmen yang besar pada organisasinya dibanding karyawan yang lainnya, kepuasan kerja akan mendorong seorang karyawan untuk berprestasi lebih baik, prestasi baik yang akan menimbulkan imbalan ekonomi bagi perusahan serta, apabila imbalan tersebut dipandang adil maka akan timbul perasaan puas sesuai 
dengan prestasinya begitu juga sebaliknya (Rahwana, K \& Lestari, 2019). Jadi, dari penjelasan teori tersebut dapat disimpukan bahwa guru honorer SMA Swasta Bukittinggi memiliki kepuasan kerja yang tinggi dengan loyalitas kerja. Selain itu, juga dapat dilihat dari tabel kriteria kategori kepuasan kerja yang memproleh paling banyak pada kategori tinggi, sehingga dapat disimpulkan bahwa subjek dalam penelitian ini memiliki kepuasan kerja yang baik.

Hasil pengkategorian skala kepuasan kerja pada masing- masing aspek, dimana kepuasan kerja memiliki sembilan aspek menurut (Spector, P, 1985) yaitu gaji, promosi, supervisi, tunjangan, imbalan kontingen, prosedur, rekan kerja, sifat pekerjaan, dan komunikasi. Rata-rata aspek kepuasan kerja berada pada kategori tinggi pada beberapa aspek seperti gaji, supervisi, prosedur dan komunikasi dari pada populasi sebelumnya. Dan juga subjek penelitian ini secara umum lebih rendah pada bagian aspek promosi, tunjangan, imbalan kontingen, rekan kerja dan sifat pekerjaan. Gaji mengukur seberapa puas tidaknya karyawan terhadap gaji yang ia teirma. Semakin tinggi skor yang diperoleh ini mengindikasikan bahwa karyawan tersebut puas dengan gaji yang ia terima begitu juga sebaliknya. Hal ini membuktikan bahwa guru-guru honorer SMA Swasta Bukittinggi menerima semua gaji yang diberikan dan merasa puas apa yang ia terima selama menajdi seorang guru.

Menurut Hasibuan (dalam Sianipar \& Salim, 2019) loyalitas adalah unsur yang digunakan pada penilaian karyawan mencakup kesetiaan terhadap pekerjaan, jabatan serta organisasi, dimana kesetiaan ini tercermin melalui kesediaan karyawan dalam membela dan menjaga suatu organisasi. Berdasarkan hasil pada penelitian ini, menunjukkan bahwa loyalitas kerja yang sangat tinggi pada guru honorer SMA Swasta Bukittinggi hal ini dikarenakan guru-guru honorer tersebut memiliki kepuasan kerja yang tinggi pula dalam menjadi seorang guru selama ini. Berdasarkan hasil pengolahan data pada pengkategorian skala loyalitas kerja diperoleh kesimpulan bahwa kebanyakan guru honorer berada pada kategori sangat tinggi. Hal ini juga sesuai dengan teori bahwa Loyal ini berasal dari hasil kepuasan kerja seseorang dari proses evaluasi internal dan jika tingkat harapan terpenuhi maka loyalitas akan tumbuh. Kemudian loyalitas karyawan berkembang menjadi sikap emosional. Dengan kata lain, semakin banyak seseorang karyawan merasa puas dengan pekerjaan dan lingkungan, maka semakin besar kemungkinan rasa komitmen atau loyal karyawan tersebut terhadap organisasinya (Rajput et al., 2016). Jadi dapat disimpulkan bahwa guru honorer SMA Swasta Bukittinggi memiliki kepuasan kerja yang tinggi. Selain itu juga dapat dilihat dari tabel kriteria kategori loyalitas kerja memperoleh paling banyak pada kategori sangat tinggi, sehingga dapat dismpulkan bahwa subjek penelitian disini loyalitas kerja yang tinggi.

Hasil pengkategorian skala loyalitas kerja pada masing-masing aspek, dimana loyalitas kerja memiliki enam aspek menurut (Siswanto, 2010) yaitu taat pada peraturan, tanggung jawab pada instansi, kemauan untuk bekerjasama, rasa memiliki, hubungan antar pribadi dan kesukaan terhadap pekerjaan, semua aspek pada loyalitas kerja berada pada kategori sangat tinggi. Taat pada peraturan merupakan suatu kebijakan yang diterapakan dalam instansi untuk memperlancar dan mnegatur jalannya pelaksanaan tugas oleh manajemen instansi ditaati dan dilaksanakan dengan baik.

Hal ini memperlihatkan bahwa semua guru honoror SMA Swasta Bukittinggi, mengikuti semua kebijakan yang diterapkan oleh instansi / sekolah dalam pelaksanaan tugas yang di manajemeni dengan baik oleh semua guru honorer tersebut. Berdasarkan dari pembahasan diatas, dapat disimpulkan bahwa penelitian ini yang berjudul“ hubungan kepuasan kerja dengan loyalitas kerja pada guru honorer SMA Swasta Bukittinggi" mendapatkan hasil kepuasan kerja yang tinggi dengan loyalitas yang tinggi secara signifikan kearah korelasi positif. Artinya semakin tinggi kepuasan kerja guru honorer SMA Swasta Bukittinggi maka semakin tinggi juga loyalitas kerja guru honorer SMA Swasta 
Bukittinggi. Begitu juga sebaliknya, semakin rendah kepuasan kerja guru honorer SMA Swasta Bukittinggi maka semakin rendah pula loyalitas kerja guru honorer SMA Swasta Bukittinggi.

\section{Kesimpulan}

Berdasarkan dari hasil penelitian yang sudah dilakukan serta pengujian hipotesis mengenai kepuasan kerja dengan loyalitas kerja pada guru honorer SMA Swasta Bukittinggi, maka dapat disimpulkan sebagai berikut :

1. Terdapat hubungan yang sangat signifikan antara kepusan kerja dengan loyalitas kerja pada guru honorer SMA Swasta Bukittinggi dengan arah korelasi positif. Hal ini semakin tinggi kepuasan kerja guru honorer SMA Swasta Bukittinggi maka semakin tinggi juga loyalitas kerja guru honorer SMA Swasta Bukittinggi dan beitu juga sebaliknya semakin rendah kepuasan kerja guru honorer SMA Swasta Bukittinggi maka semakin rendah pula loyalitas kerja guru honorer SMA Swasta Bukittinggi.

2. Secara umum guru honorer SMA Swasta Bukittinggi memiliki kepuasan kerja yang tinggi.

3. Secara umum guru honorer SMA Swasta Bukittinggi memiliki loyalitas kerja yang tinggi.

\section{DAFTAR RUJUKAN}

Adler, P. A., \& Adler, P. (1988). Intense loyalty in organizations: A case study of college athletics. Journal administrative science quarterly, 33(3), 401-417.

Arqawi, S. M., Al, A. A., Naser, S. S. A., \& Shobaki, M. J. Al. (2018). Interactive justice as an approach to enhance organizational loyalty among faculty staff at Palestine Technical University- ( Kadoorei ). International journal of academic information systems research (ijaisr), 2(9), 17-28.

Basalamah, A. (2012). Pengaruh kepuasan kerja terhadap loyalitas staf reception pada hotel $x$ di Madiun Jawa Timur. Binus business review, 3(1), 493. https://doi.org/10.21512/bbr.v3i1.1337

Budi, O. (2019, October). Kisah memprihatinkan gaji guru honorer yang jauh dari kata sejahtera. 17 Juli 2019. Retrieved from https://id.berita.yahoo.com/kisah-memprihatinkan-gaji-guru-honorer070057324.html

Hadiutama, J. (2008). Hubungan antara kepuasan kerja dengan loyalitas karyawan studi kasus terhadap karyawan universitas sanata dharma Yogyakarta. Universitas Sanata Dharma Yogyakarta.

Locke, E. A. (1969). What is job satisfaction ? 4, 309-336.

Mariana, R \& Irfani, H. (2015). Hubungan kepuasan kerja dengan loyalitas kerja perawat honor Rsud Kabupaten Padang Pariaman. Jurnal rap unp, 6, 193-202.

Meiza, C. (2016). Perbedaan kebahagiaan pada guru berstatus PNS dan honorer. Jurnal ilmiah psikologi, 9(2).

Peraturan.bpk.go.id. (2005). Pengangkatan tenaga honorer menjadi calon pegawai negeri sipil. Retrieved February 21, 2020, from https://peraturan.bpk.go.id website: 
https://peraturan.bpk.go.id/Home/Details/49667/pp-no-48-tahun-2005

Rahwana, K, A., \& Lestari, S. P. (2019). Pengaruh kepuasan kerja terhadap loyalitas pegawai dinas pertanian Kabupaten Pangandaran. Jurnal ekonomi perjuangan (jumper), 1(2), 89-99.

Rajput, S., Singhal, M., \& Tiwari, S. (2016). Job satisfaction and employee loyalty: A study of academicians. Asian j. management, $7(2)$.

Sariwulan, T., Agung, I., Sudrajat, U., \& Atmadiredja, G. (2019). The influence of job expectation, job satisfaction, and government policy towards the work stress, job enthusiasm and continuance commitment of the honorarium teacher. Cakrawala pendidikan, 38(2), 305-319. https://doi.org/10.21831/cp.v38i2.24380

Sianipar, R., \& Salim, V. (2019). Faktor etos kerja dan lingkungan kerja dalam membentuk " loyalitas kerja " pegawai. Jurnal ilmiah akuntansi dan manajemen (jiam), 15(1), 15-27.

Siswanto. (2010). Pengantar manajemen. Jakarta: Bumi aksara.

Spector, P, E. (1985). Measurement of human service staff satisfaction: Development of the job satisfaction survey. American journal of community psychology, 13(6).

Statistik.data.kemdikbud.go.id. (n.d.). Pusat data statistik dan pendidikan. Retrieved October 20, 2019, from http://statistik.data.kemdikbud.go.id/

Sugiyono. (2013). Metode penelitian kualitatif kuantitatif $d$ r\&d. Bandung: Alfabeta.

Tri, G. (2019). Apakah senyum guru honorer merkah di tahun 2019 ini ? Kompasiana.Com. Retrieved from

http://www.google.com/amp/s/www.kompasiana.com/amp/gatot_tri/5ccda0a63ba7f7218069 b832/apakah-senyum-guru-honorer-merekah-di-tahun-2019-ini

Winarsunu, T. (2009). Statistik dalam penelitian psikologi dan pendidikan. Malang: Umm.

Yusuf, M. (2010). Metodologi penelitian : Dasar - dasar penyelidikan ilmiah. Padang: Unp press. 